\section{Men's health: a population-based study on social inequalities}

\author{
A saúde dos homens: desigualdades sociais em \\ estudo de base populacional
}

\begin{abstract}
This study evaluates social inequalities in health according to level of schooling in the male population. This was a cross-sectional, populationbased study with a sample of 449 men ranging from 20 to 59 years of age and living in Campinas, São Paulo State, Brazil. The chi-square test was used to verify associations, and a Poisson regression model was used to estimate crude and adjusted prevalence ratios. Men with less schooling showed higher rates of alcohol consumption and dependence, smoking, sedentary lifestyle during leisure time, and less healthy eating habits, in addition to higher prevalence of bad or very bad self-rated health, at least one chronic disease, hypertension, and other health problems. No differences were detected between the two schooling strata in terms of use of health services, except for dental services. The findings point to social inequality in health-related behaviors and in some health status indicators. However, possible equity was observed in the use of nearly all types of health services.
\end{abstract}

Men's Health; Social Inequity; Health Surveys
Tássia Fraga Bastos 1

Maria Cecília Goi Porto Alves 2

Marilisa Berti de Azevedo Barros 1

Chester Luiz Galvão Cesar 3

\section{Introduction}

Male excess mortality in practically all age groups, extensively documented in the literature, entails different life expectancies for men and women 1,2,3,4. In Brazil, this difference is currently some 7.6 years (69.4 and 77.0 years for men and women, respectively), resulting in a significantly smaller male population in the older age groups 5. Although women report higher diseases prevalence rates, when disease severity is analyzed, men normally present higher rates of chronic diseases with high lethality 6 .

Given this scenario, the Brazilian Ministry of Health took an important step in 2009 when it launched the National Policy for Integral Attention to Men's Health (PNAISH), which aims to promote improvements in the health of the Brazilian male population, contributing to the reduction of morbidity and mortality by means of addressing the risk factors and facilitating access to actions and services for comprehensive health care, with primary care as the gateway preferential of Brazilian Unified National Health System (SUS) 7 .

According to Courtenay ${ }^{8}$, hegemonic masculinity is the socially dominant gender construct that reflects and shapes social relations between men and women and among men. This construct is based on the hegemonic ideals and represents power and authority, necessary attributes for constituting men as such and their health-relat- 
ed beliefs and behaviors, the results of a social construction. In the constant quest for the ideals of manhood, power, and privilege, men are frequently led to adopt harmful health behaviors, with the emergence of relevant risk factors for illness 1,8,9.

Various studies have analyzed how socioeconomic, ethnic/racial, regional, and gender inequalities impact the morbidity and mortality profile and access and use of health services 10 . However, few studies have focused on men's health and the effects of social inequalities 1,2. According to Muntaner et al. 11, measurements of social stratification, including level of schooling, are important predictors of morbidity and mortality patterns, and various studies have assessed the relationship between such indicators and health outcomes. Information on complete years of schooling has advantages over other measures of social stratification because it is universal, easy to collect, and stable over the individual's lifetime 12 .

Based on the above and considering the male population's vulnerability, especially at younger ages, this study aims to evaluate social inequalities in health according to schooling, among men 20 to 59 years of age living in Campinas, São Paulo State, Brazil.

\section{Methods}

This is a cross-sectional, population-based study, the data for which were obtained from the Campinas Health Survey (ISA-Camp) conducted in 2008-2009. Data were collected by previously trained interviewers, using a questionnaire organized in thematic sections: morbidity, accidents and violence, mental health, quality of life, use of health services, preventive practices, use of medicines, health-related behaviors, and socioeconomic characteristics.

The survey's sample was obtained by twostage probabilistic sampling. Initially, 50 census tracts from the urban area of the City of Campinas were selected, with probability proportional to size, defined as the number of households, followed by a field survey to identify the existing private households in the selected tracts.

The households were selected in the second stage, aimed at conducting 20 interviews in each census tract for three population subgroups: adolescents (10 to 19 years), adults (20 to 59 years), and elderly (60 years or older), which constituted the study domains.

Samples of equal sizes were selected, with one thousand individuals for each domain. The number of interviews would allow estimating proportions of 0.50 with a sampling error of 4 to 5 percentage points for a $95 \%$ confidence interval and design effect of 2 .

The data analyzed in the current study refer to the male population in the 20-59-year age bracket. For this group, the sampling error would be on the order of $6.2 \%$. According to data from the 2000 Population Census (Instituto Brasileiro de Geografia and Estatística; http://www.ibge.gov. br), one thousand adults would be found by visiting 522 households. Providing for refusals and closed households (a total of $20 \%$ ), 700 households were sampled. The sampling design for the ISA-Camp 2008 survey has been described in detail by Alves 13 .

The variables analyzed in the current study include:

a) Demographic and socioeconomic: interviewee's level of schooling (complete years of schooling); age; self-reported race/color; birthplace; religion; marital status; number of persons in the household; current occupation; type of worker; number of household assets; monthly per capita family income (in times the minimum wage); private health plan coverage; dental coverage;

b) Health-related behaviors: alcohol dependence (measured by the Alcohol Use Disorders Identification Test - AUDIT, with 8 points or more considered positive for dependence) 14 ; frequency of alcohol consumption $(<4$ times/week and $\geq 4$ times/week); current smoker; smoking cessation, defined as the percentage of ex-smokers among those who have ever smoked (current smokers and ex-smokers); passive smoker (non-smoker exposed to cigarette smoke at least 1 hour per day); leisure-time physical activity: active (at least 150 minutes per week, on 3 days of the week), insufficiently active (less than 150 minutes per week or on fewer than 3 days in the week), sedentary (no time devoted to leisure-time physical activity in the week); body mass index (BMI) according to World Health Organization (WHO) guidelines 15 for adults: underweight $\left(<18.5 \mathrm{~kg} / \mathrm{m}^{2}\right)$, normal weight $\left(18.5\right.$ to $\left.<25 \mathrm{~kg} / \mathrm{m}^{2}\right)$, overweight $(25$ to $<$ $30 \mathrm{~kg} / \mathrm{m}^{2}$ ), excess weight ( $\geq 25 \mathrm{~kg} / \mathrm{m}^{2}$ ); and obese $\left(\geq 30 \mathrm{~kg} / \mathrm{m}^{2}\right.$ ); consumption of fruit, vegetables, leafy vegetables, and milk fewer than 7 days a week; daily soft drink (soda) consumption;

c) health status: bad or very bad self-rated health; common mental disorder (CMD), defined according to the Self-Reporting Questionnaire (SRQ-20), with greater than 8 points defined as presence of CMD 16; the following diseases reported as having been diagnosed by a health professional, based on a checklist: arterial hypertension (high blood pressure), heart disease, asthma, bronchitis, emphysema, tendinitis, RSI/WRMD, circulatory problems; self-reported health problems 
not diagnosed by a health professional: frequent headache or migraine, back pain or problem with spinal column, allergy, emotional problem, dizziness or vertigo, visual impairment (total or partial), use of eyeglasses or contact lenses, and use of dental prostheses; accidents in the previous year;

d) Use of health services: use of health services in the 15 days prior to the interview; hospitalizations in the previous 12 months; surgery any time in life and in the previous 12 months; dental visit in the previous 12 months; consumption of medicines in the previous 3 days; preventive tests for men 40 to 59 years of age: PSA and digital rectal examination in the previous year; routine medical consultation for individuals with arterial hypertension.

The dependent variables were all those related to health behaviors and conditions and use of health services, while the principal independent variable was schooling, categorized as 0 to 8 versus 9 or more years of school. Demographic and socioeconomic variables were used to characterize the study population. The estimated prevalence ratios were adjusted for age, and in the case of use of health services (medical consultations, hospitalization, surgeries, and consumption of medicines), for age and number of chronic diseases, to control for confounding.

Analysis of the associations between dependent and independent variables used the chisquare test with $5 \%$ statistical significance, and the crude and adjusted prevalence ratios (PR) and respective 95\% confidence intervals (95\%CI) were estimated using Poisson regression. Data were analyzed with Stata 11.0 (Stata Corp., College Station, USA), which considers the different weights of individuals comprising the sample, as well as the sample design effect. The study was approved by the Institutional Review Board of the School of Medicine, State University in Campinas (Faculdade de Medicina, Universidade Estadual de Campinas - UNICAMP), under case file 079/2007.

\section{Results}

Data were analyzed from a probabilistic sample of 449 men living in Campinas, ranging from 20 to 59 years of age, with a mean of 37 years $(95 \% \mathrm{CI}$ : $36.02-37.95)$. In this population, $35.7 \%$ (95\%CI: 27.9-44.3) reported 0 to 8 years of schooling, while the rest had 9 years or more. Except for religion, the demographic and socioeconomic characteristics showed statistically significant differences ( $p<0.05$ ) between men from the two schooling strata (Table 1). Men with less schooling showed higher proportions of non-white individuals, those born in other States, with lower income, and less medical and dental coverage. There were also proportionally more unemployed individuals among those with less schooling. Proportionally more men with more schooling had 15 or more household assets.

As for health-related behaviors (Table 2), there were higher rates of alcohol dependence, alcohol consumption four or more times a week, and smoking among men with less schooling. For leisure-time physical activity, there were proportionally more sedentary men among those with less schooling. Analyzing food consumption, men with less schooling shower a higher proportion of non-daily consumption (less than 7 days of week) of fruit, vegetables, and leafy vegetables.

As shown in Table 3, the male population with less schooling showed a higher prevalence of bad or very bad self-rated health and at least one chronic disease, arterial hypertension, frequent headache or migraine, and backache. Other diseases were not significantly associated with level of schooling. Visual impairment was significantly more prevalent in men with less schooling, who were also less likely to use eyeglasses or contact lenses when compared to men with more schooling. Use of dental prosthesis was also significantly more prevalent in men with less schooling.

Analysis of use of health services only showed a statistically significant difference for dental services in the previous year (men with less schooling were less likely to have used such services, as shown in Table 4). The other variables related to use of health services showed no significant differences between the two schooling strata.

\section{Discussion}

This study's findings point to the magnitude of social inequality among adult men in Campinas; those with less schooling were underprivileged in relation to health-related behaviors, health conditions, and use of dental services.

Men with less schooling were significantly more likely to consume alcohol four or more times a week (PR $=2.97$; 95\%CI: 1.38-6.41). Another study in Campinas had shown similar results 17 . On the other hand, other studies have shown a higher prevalence of excessive alcohol intake in the social stratum with more schooling 18,19 .

Prevalence of alcohol dependence or abuse, as evaluated by AUDIT, was $15.9 \%$, and men with less schooling showed a $67 \%$ greater probability of being alcohol-dependent as compared to those with more schooling. This inverse associa- 
Table 1

Socioeconomic and demographic characteristics (\%) of the male population 20 to 59 years of age according to schooling Campinas, São Paulo State, Brazil, ISA-Camp 2008-2009.

\begin{tabular}{|c|c|c|c|c|c|}
\hline \multirow[t]{3}{*}{ Variable } & \multirow[t]{3}{*}{$\mathbf{n}$} & \multicolumn{2}{|c|}{ Schooling (years) } & \multirow{3}{*}{$\begin{array}{c}\text { Total } \\
\%\end{array}$} & \multirow[t]{3}{*}{ p-value } \\
\hline & & 0 to $8(n=166)$ & $\geq 9(n=283)$ & & \\
\hline & & $\%$ & $\%$ & & \\
\hline Age bracket (years) & & & & & 0.0003 \\
\hline $20-29$ & 155 & 23.5 & 41.7 & 35.2 & \\
\hline $30-39$ & 101 & 21.6 & 23.7 & 22.9 & \\
\hline $40-49$ & 98 & 24.7 & 19.2 & 21.2 & \\
\hline $50-59$ & 95 & 30.2 & 15.4 & 20.7 & \\
\hline Race/Color & & & & & 0.0006 \\
\hline White & 327 & 60.4 & 80.5 & 73.3 & \\
\hline Non-white & 120 & 39.6 & 19.5 & 26.7 & \\
\hline Birthplace & & & & & 0.0002 \\
\hline Campinas & 179 & 28.8 & 46.5 & 40.1 & \\
\hline Other county in São Paulo & 136 & 27.8 & 31.7 & 30.3 & \\
\hline Other State of Brazil & 134 & 43.5 & 21.9 & 29.6 & \\
\hline Religion & & & & & 0.4855 \\
\hline Catholic & 220 & 45.1 & 51.4 & 49.1 & \\
\hline Protestant & 131 & 32.6 & 27.0 & 29.0 & \\
\hline No religion/Other & 96 & 22.3 & 21.6 & 21.9 & \\
\hline Marital status & & & & & 0.0003 \\
\hline Married & 208 & 50.1 & 43.7 & 46.0 & \\
\hline Common-law & 72 & 23.7 & 11.7 & 16.0 & \\
\hline Divorced/Widowed & 36 & 8.5 & 7.6 & 7.9 & \\
\hline Single & 133 & 17.7 & 37.0 & 30.1 & \\
\hline Number of persons in household & & & & & 0.0004 \\
\hline $1-2$ & 104 & 21.6 & 24.2 & 23.3 & \\
\hline $3-4$ & 226 & 39.7 & 56.6 & 50.6 & \\
\hline$\geq 5$ & 119 & 38.6 & 19.3 & 26.2 & \\
\hline Current occupational status & & & & & 0.0121 \\
\hline Working & 383 & 81.4 & 87.6 & 85.4 & \\
\hline Unemployed & 33 & 10.3 & 5.5 & 7.2 & \\
\hline Retired/Pensioner & 22 & 7.7 & 3.0 & 4.7 & \\
\hline Student/other & 11 & 6.1 & 3.8 & 2.7 & \\
\hline Type of worker & & & & & 0.0074 \\
\hline Wage-earner & 310 & 63.2 & 75.6 & 71.1 & \\
\hline Self-employed/Other & 126 & 36.8 & 24.4 & 28.9 & \\
\hline Household assets & & & & & $<0.0001$ \\
\hline$<10$ & 170 & 60.3 & 24.5 & 37.3 & \\
\hline $10-14$ & 140 & 25.3 & 34.3 & 31.1 & \\
\hline$\geq 15$ & 138 & 14.4 & 41.2 & 31.6 & \\
\hline Family income (minimum wages) & & & & & $<0.0001$ \\
\hline$\leq 1$ & 171 & 56.0 & 27.1 & 37.4 & \\
\hline$>1-3$ & 194 & 39.1 & 45.2 & 43.0 & \\
\hline$>3$ & 84 & 4.9 & 27.7 & 19.6 & \\
\hline Private health plan & & & & & $<0.0001$ \\
\hline Yes & 189 & 14.3 & 58.9 & 43.0 & \\
\hline No & 260 & 85.7 & 41.1 & 57.0 & \\
\hline Dental plan & & & & & $<0.0001$ \\
\hline Yes & 88 & 6.0 & 27.9 & 20.1 & \\
\hline No & 361 & 94.0 & 72.1 & 79.9 & \\
\hline
\end{tabular}


Table 2

Prevalence (\%) and prevalence ratios (PR) for health-related behaviors in the male population 20 to 59 years of age according to schooling. Campinas, São Paulo State, Brazil, ISA-Camp 2008/2009.

\begin{tabular}{|c|c|c|c|c|c|}
\hline \multirow[t]{3}{*}{ Variables } & \multicolumn{2}{|c|}{ Schooling (years) } & \multirow[t]{3}{*}{$\mathrm{p}$-value * } & \multirow{3}{*}{$\begin{array}{l}\text { Crude PR } \\
(95 \% \mathrm{Cl})\end{array}$} & \multirow[t]{3}{*}{ Adjusted PR $(95 \% \mathrm{Cl})$ ** } \\
\hline & 0 to $8(n=166)$ & $\geq 9(n=283)$ & & & \\
\hline & $\%$ & $\%$ & & & \\
\hline Alcohol consumption $\geq 4$ times/week & 17.4 & 4.3 & 0.0002 & $4.06(1.91-8.62)$ & $2.97(1.38-6.41)$ \\
\hline Alcohol dependence & 21.7 & 12.6 & 0.0181 & $1.72(1.10-2.67)$ & $1.67(1.03-2.70)$ \\
\hline Current smoker & 36.7 & 18.2 & $<0.001$ & $1.15(1.09-1.23)$ & $1.15(1.08-1.23)$ \\
\hline Stopped smoking & 29.8 & 35.5 & 0.4281 & $0.84(0.54-1.30)$ & $0.79(0.54-1.15)$ \\
\hline Passive smoker & 18.1 & 19.2 & 0.9981 & $1.00(0.58-1.72)$ & $1.17(0.65-2.12)$ \\
\hline Sedentary during leisure time & 70.9 & 50.0 & 0.0004 & $1.42(1.20-1.67$ & $1.33(1.11-1.59)$ \\
\hline Consumption of fruit $<7$ days/week & 77.7 & 66.2 & 0.0118 & $1.17(1.04-1.33)$ & $1.25(1.10-1.42)$ \\
\hline $\begin{array}{l}\text { Consumption of leafy vegetables }<7 \text { days/ } \\
\text { week }\end{array}$ & 68.5 & 46.7 & 0.0003 & $1.47(1.21-1.78)$ & $1.55(1.27-1.90)$ \\
\hline Consumption of vegetables $<7$ days/week & 77.1 & 63.1 & 0.0028 & $1.22(1.08-1.38)$ & $1.27(1.11-1.45)$ \\
\hline Consumption of milk $<7$ days/week & 54.6 & 51.7 & 0.5608 & $1.06(0.87-1.28)$ & $1.07(0.86-1.32)$ \\
\hline Consumption of soft drinks 7 days/week & 26.5 & 24.5 & 0.7027 & $1.08(0.71-1.64)$ & $1.69(0.76-1.80)$ \\
\hline
\end{tabular}

* $\mathrm{p}$-value for chi-square test;

** Age-adjusted PR; reference category: 9 or more years of schooling.

Table 3

Prevalence (\%) and prevalence ratios (PR) for health status in the male population 20 to 59 years of age according to schooling. Campinas, São Paulo State, Brazil, ISA-Camp 2008-2009.

\begin{tabular}{|c|c|c|c|c|c|}
\hline \multirow[t]{3}{*}{ Variables } & \multicolumn{2}{|c|}{ Schooling (years) } & \multirow[t]{3}{*}{ p-value * } & \multirow{3}{*}{$\begin{array}{c}\text { Crude PR } \\
(95 \% \mathrm{Cl})\end{array}$} & \multirow[t]{3}{*}{ Adjusted PR $(95 \% \mathrm{Cl})$ ** } \\
\hline & 0 to $8(n=166)$ & $\geq 9(n=283)$ & & & \\
\hline & $\%$ & $\%$ & & & \\
\hline Bad or very bad self-rated health & 10.3 & 3.1 & 0.0048 & $3.34(1.40-7.99)$ & $2.91(1.19-7.09)$ \\
\hline Common mental disorder & 10.4 & 5.3 & 0.0422 & $1.94(1.02-3.69)$ & $1.74(0.87-3.45)$ \\
\hline Disease in previous 15 days & 15.1 & 14.5 & 0.8650 & $1.04(0.64-1.69)$ & $1.01(0.62-1.65)$ \\
\hline At least one chronic disease & 41.6 & 25.8 & 0.0018 & $1.61(1.20-2.16)$ & $1.36(1.02-1.79)$ \\
\hline Hypertension & 19.1 & 7.3 & 0.0004 & $2.60(1.54-4.39)$ & $1.85(1.11-3.09)$ \\
\hline Heart disease & 3.6 & 2.5 & 0.4662 & $1.44(0.53-3.94)$ & $1.14(0.39-3.37)$ \\
\hline Asthma/Bronchitis/Emphysema & 3.0 & 2.5 & 0.7343 & $1.20(0.41-3.47)$ & $1.33(0.44-3.96)$ \\
\hline Tendinitis/RSI/WRMD & 6.2 & 3.6 & 0.1533 & $1.71(0.81-3.63)$ & $1.57(0.68-3.60)$ \\
\hline Circulatory problems & 7.8 & 3.8 & 0.0827 & $2.04(0.89-4.66)$ & $1.45(0.63-3.37)$ \\
\hline Headache/Migraine & 29.6 & 15.7 & 0.0031 & $1.89(1.26-2.82)$ & $2.01(1.35-2.98)$ \\
\hline Backache/Problems with spinal column & 35.4 & 22.4 & 0.0084 & $1.58(1.14-2.19)$ & $1.44(1.03-2.01)$ \\
\hline Allergy & 16.9 & 26.4 & 0.0497 & $0.64(0.40-1.02)$ & $0.69(0.43-1.10)$ \\
\hline Emotional problem & 12.1 & 11.1 & 0.7583 & $1.09(0.62-1.91)$ & $0.95(0.54-1.66)$ \\
\hline Dizziness/Vertigo & 7.1 & 4.3 & 0.1347 & $1.64(0.85-3.20)$ & $1.47(0.79-2.75)$ \\
\hline Insomnia & 12.1 & 8.2 & 0.2941 & $1.47(0.71-3.06)$ & $1.19(0.57-2.45)$ \\
\hline Excess weight & 52.7 & 47.9 & 0.4591 & $1.10(0.85-1.42)$ & $1.02(0.80-1.30)$ \\
\hline Obesity & 13.4 & 16.6 & 0.4472 & $0.80(0.45-1.43)$ & $0.68(0.38-1.20)$ \\
\hline Visual impairment & 17.6 & 6.6 & 0.0011 & $2.67(1.48-4.80)$ & $2.03(1.13-3.64)$ \\
\hline Eyeglasses/Contact lenses & 32.0 & 39.1 & 0.1688 & $0.82(0.61-1.10)$ & $0.65(0.51-0.82)$ \\
\hline Dental prosthesis & 21.0 & 7.6 & 0.0001 & $2.76(1.70-4.48)$ & $1.93(1.18-3.16)$ \\
\hline Accident(s) in previous year & 9.8 & 9.1 & 0.8091 & $1.08(0.57-2.04)$ & $1.19(0.62-2.27)$ \\
\hline
\end{tabular}

RSI: repetitive strain injury; WRMD: work-related musculoskeletal disorder.

* p-value for chi-square test;

** Age-adjusted PR; reference category: 9 or more years of schooling. 
Prevalence (\%) and prevalence ratios (PR) for use of health services by male population 20 to 59 years of age according to schooling (in years). Campinas, São Paulo State, Brazil, ISA-Camp 2008-2009.

\begin{tabular}{|c|c|c|c|c|c|}
\hline \multirow[t]{4}{*}{ Variables } & \multicolumn{2}{|c|}{ Schooling (years) } & \multirow[t]{4}{*}{ p-value * } & \multirow{4}{*}{$\begin{array}{l}\text { Crude PR } \\
(95 \% \mathrm{Cl})\end{array}$} & \multirow[t]{4}{*}{ Adjusted PR (95\%Cl) } \\
\hline & 0 to 8 & $\geq 9(n=283)$ & & & \\
\hline & \multicolumn{2}{|l|}{$(n=166)$} & & & \\
\hline & $\%$ & $\%$ & & & \\
\hline Medical consultation in previous 15 days & 11.6 & 15.4 & 0.3105 & $0.75(0.42-1.33)$ & $0.59(0.31-1.15) * \star$ \\
\hline Hospitalization in previous year & 8.3 & 5.9 & 0.2837 & $1.41(0.75-2.65)$ & $1.10(0.58-2.06)$ ** \\
\hline Surgery in previous year & 6.7 & 11.6 & 0.2893 & $0.57(0.20-1.67)$ & $0.52(0.18-1.52)$ ** \\
\hline Use of medicines in previous 3 days & 44.8 & 38.8 & 0.2327 & $1.16(0.91-1.46)$ & $0.90(0.72-1.12) * \star$ \\
\hline Dental visit in previous year & 39.6 & 62.8 & 0.0015 & $0.63(0.47-0.85)$ & $0.61(0.45-0.82) * \star \star$ \\
\hline PSA (40 to 59 years of age) & 41.7 & 55.4 & 0.1007 & $0.89(0.74-1.07)$ & $0.87(0.73-1.05) * \star \star$ \\
\hline $\begin{array}{l}\text { Digital rectal examination ( } 40 \text { to } 59 \text { years } \\
\text { of age) }\end{array}$ & 26.0 & 34.3 & 0.1927 & $0.94(0.81-1.08)$ & $0.93(0.79-1.08) * \star \star$ \\
\hline Routine checkup for individuals with hypertension & 56.6 & 75.3 & 0.2018 & $0.75(0.49-1.14)$ & $0.73(0.48-1.10) * \star \star$ \\
\hline
\end{tabular}

* p-value for chi-square test;

** PR adjusted for age and number of chronic diseases; reference category: 9 or more years of schooling;

*** Age-adjusted PR; reference category: 9 or more years of schooling.

tion between schooling and alcohol dependence is consistent with the results of health surveys in Campinas in 2003 20, detected by the CAGE test 21 , and in the city of Rio Grande, Rio Grande do Sul State 22 . There is a lack of consensus concerning the profile for frequent alcohol consumption and alcohol abuse according to different socioeconomic strata, although most studies indicate higher frequency of intake among individuals with higher socioeconomic status, while alcohol dependence is more common in the lower socioeconomic stratum 23 .

The current study showed an association between smoking and level of schooling, with a higher proportion of current smokers among men with less schooling (36.7\%). This prevalence exceeds the estimates for socially more vulnerable segments in Brazil (24.2\%) and in the city of São Paulo (28\%) according to a telephone health survey in 2006, focusing on males 18 years or older 24 . An inverse association between schooling and smoking, as found in the current study, is a consensus in the Brazilian and international literature 18,25,26,27.

Among men with less education, $70.9 \%$ were considered sedentary as defined by lack of leisure-time physical activity, and they were 1.33 times more likely (95\%CI: 1.11-1.59) to be inactive as compared to men with more schooling. An inverse association between schooling and sedentary lifestyle was also found in health surveys conducted in the State of São Paulo, considering men 18 to 59 years of age 28 , and in Greater Metropolitan Belo Horizonte, Minas Gerais State 18. The high percentage of sedentary lifestyle among men in Campinas suggests a lack of stimuli and adequate locations for practicing physical activities, especially for men with lower socioeconomic status.

Non-daily consumption (fewer than 7 days a week) of fruit, vegetables, and leafy vegetables reached prevalence ratios of 1.25 (95\%CI: 1.101.42), 1.55 (95\%CI: 1.27-1.90), and 1.27 (95\%CI: 1.11-1.45), respectively, in the male population with less schooling in Campinas. Similar results have been shown elsewhere in the literature 29,30.

Bad or very bad self-rated health was found among $10.3 \%$ of men with less schooling, and was 2.91 times more frequent (95\%CI: 1.97-7.09) than among those with more schooling. Other studies have found an inverse association between schooling and self-rated health 31,32,33. According to Dachs 31, age is the single most important factor in self-rated health, but schooling and income show relevant additional contributions to this health dimension.

The presence of one or more chronic diseases was significantly associated with level of schooling; prevalence was higher among men with lower socioeconomic status. Similar results were found in the Brazilian adult population (18 years or older), based on data from the Brazilian $\mathrm{Na}$ tional Household Sample Survey (PNAD 2008) 34, and in the population 30 years or older, accord- 
ing to the Telephone Survey for the Surveillance of Risk and Protective Factors for Chronic Diseases (VIGITEL 2006) ${ }^{35}$. The same relationship has been published in the international literature 36,37 .

With the exception of allergy, all the chronic diseases and self-reported health problems showed higher prevalence rates among men with less schooling. However, statistically significant differences were only observed for hypertension, frequent headache or migraine, backache, and visual impairment.

Arterial hypertension was associated with level of education, showing higher prevalence in men with less schooling. Similar findings have been observed for Brazilian adults 20 to 64 years of age, pointing to inequality between different social segments (defined by per capita family income) 38 in the population 18 to 39 years of age in the United States National Health and Nutrition Examination Surveys (NHANES), conducted from 1999 to 2004 39, and among American men 20 years and older 40 .

As in the current study, in Portugal 41 and in Pelotas, Rio Grande do Sul State, Brazil, 42 headache and backache were associated with level of schooling, with prevalence inversely associated with schooling, a relationship that was mediated by the greater exposure of individuals with less schooling to heavy work overload, both at home and at work, among other factors 43 .

Visual impairment was associated with level of schooling and was more prevalent in the lower socioeconomic stratum, thus corroborating other studies in four cities in São Paulo State 44, in Campinas 23, and in the United States 45. This inverse association was probably due to the fact that individuals with lower income and less schooling have less access to services that allow detection of their visual impairments or access to eyeglasses and contact lenses. The latter assumption was supported by this study, showing a lower proportion of use of eyeglasses and contact lenses among men with less schooling.

Use of dental prosthesis was more prevalent among men with less schooling. This calls attention to the problem of early tooth loss, a marker for social inequality 46 that reflects less access to quality dental services.

Except for dental care, there were no statistically significant differences between men from different schooling strata in relation to the use of services, which could indicate a tendency toward equity in access in Campinas in terms of use of health services in general. Although the sample size may have prevented the study from detecting statistical differences between the two strata in access to health services, a similar result ap- peared in the elderly population in Campinas in the same household survey cited in the current study, suggesting that organization of the health system in the municipality is leading to more equitable access 23 .

As for use of dental services, the study's findings are consistent with those of other studies in Brazil that have indicated the presence of socioeconomic inequalities (assessed by income or schooling), whereby individuals from more vulnerable social strata were less likely to use dental services (PR $=0.61 ; 95 \%$ CI: 0.45 0.82) 47,48. Data from the PNAD 2008 showed some attenuation in socioeconomic inequality over the years in the use of dental services, but still with a persistent degree of inequality 49 . Non-utilization of dental services is associated not only with socioeconomic issues 50 , but also with the scarce supply of public oral health services 51 .

Some limitations to this study should be considered. One was the sample size, sufficient to estimate most of the target prevalence rates, but insufficient for less frequent diseases and events. Another limitation was that the study was based on self-reporting, thus subject to information biases, which can underestimate or overestimate the real prevalence rates, such as those for socially undesirable behaviors, which tend to be underestimated 23 . In addition, the cross-sectional design does not allow establishing causal inferences between the variables. It is also possible that the social inequality shown here in relation to the presence of diseases may be underestimated, considering that individuals with less schooling tend to have less access to quality health services and diagnostic technologies, and thus would tend to underreport this information 34 .

This study is relevant as the first to use health survey data to analyze social inequalities in health in the population of young Brazilian men, the target public for the PNAISH. The study's findings can contribute to the equitable planning of strategic measures as proposed in the National Action Plan under the PNAISH 52 and developed in the SUS, considering the magnitude of social inequalities observed in most of the health-related behaviors, the prevalence rates for some diseases, and the use of dental services. Such studies are necessary to detect and monitor health determinants for men, fostering discussion on the importance of inter-sector actions that extrapolate the health sector and favoring the improvement of health indicators and decreasing early mortality in the male population. 


\section{Resumo}

Este trabalho avalia as desigualdades sociais em saúde, segundo escolaridade, na população masculina. Trata-se de um estudo transversal de base populacional, envolvendo 449 homens, de 20 a 59 anos, residentes em Campinas, São Paulo, Brasil. Realizou-se o teste qui-quadrado para verificar as associações e o modelo de regressão de Poisson para estimar as razões de prevalência brutas e ajustadas. O segmento de menor escolaridade apresentou maiores proporções de consumo e dependência de bebida alcoólica, taba gismo, sedentarismo e de consumo alimentar menos saudável, além de maiores prevalências de autoavaliação da saúde como ruim/muito ruim, pelo menos uma doença crônica, hipertensão, dentre outros problemas de saúde. Não foram detectadas diferenças entre os segmentos com relação ao uso de serviços de saúde, à exceção da utilização de serviços odontológicos. Os achados revelam que há desigualdade social na maioria dos comportamentos relacionados à saúde e em alguns indicadores de estado de saúde. Entretanto, observou-se possivel equidade no uso de praticamente todos os serviços de saúde.

Saúde do Homem; Iniquidade Social; Inquéritos Epidemiológicos

\section{References}

1. Braz M. A construção da subjetividade masculina e seu impacto sobre a saúde do homem: reflexão bioética sobre justiça distributiva. Ciênc Saúde Coletiva 2005; 10:97-104.

2. Laurenti R, Jorge MHPM, Goltlieb SLD. Perfil epidemiológico da morbi-mortalidade masculina. Ciênc Saúde Coletiva 2005; 10:35-46.

3. Secretaria Municipal de Saúde. Mortalidade em Campinas: informe do projeto de monitorização dos óbitos no município de Campinas. (Boletim no . 42, julho a dezembro de 2007, Mortalidade e Gênero). http://www.fcm.unicamp.br/centros/ccas/ arquivos/bo42.pdf (accessed on 10/Jun/2011).

\section{Contributors}

T. F. Bastos prepared the proposal, wrote the article, and planned, scheduled, and conducted the statistical analyses. M. C. G. P. Alves supervised the literature re view, data analysis, and wrote of the article. M. B. A Barros collaborated in the literature review and writing of the article. C. L. G. César collaborated in writing the article.

\section{Acknowledgments}

The authors wish to thank the CAPES for the Master's scholarship for T. F. Bastos; the CNPq for the research funding and scientific productivity grant for M. B. A Barros (grant no. 409747/2006-8); and the Brazilian Ministry of Health and the Campinas Health Department for financial support to carry out the survey (Partnership UNICAMP/Funcamp/SMS no. 4300).
4. Sala A, Mendes JDV. Perfil da mortalidade masculina no Estado de São Paulo. Boletim Epidemiológico Paulista 2010; 7:15-25.

5. Instituto Brasileiro de Geografia e Estatística. Aspectos demográficos. In: Instituto Brasileiro de Geografia e Estatística, organizador. Síntese de indicadores sociais: uma análise das condições de vida da população brasileira. Rio de Janeiro: Instituto Brasileiro de Geografia e Estatística; 2010. p. 27-44.

6. Verbrugge LM, Wingard DL. Sex differentials in health and mortality. Women Health 1987; 12: 103-45. 
7. Ministério da Saúde. Portaria no. 1944, de 27 de agosto de 2009. Institui no âmbito do Sistema Único de Saúde (SUS), a Política Nacional de Atenção Integral à Saúde do Homem. Diário Oficial da União 2009; 28 ago.

8. Courtenay WH. Constructions of masculinity and their influence on men's well-being: a theory of gender and health. Soc Sci Med 2000; 50:1385-401.

9. Gomes R, Nascimento EF. A produção do conhecimento da saúde pública sobre a relação homemsaúde: uma revisão bibliográfica. Cad Saúde Pública 2006; 22:901-11.

10. Louvison MCP, Lebrão ML, Duarte YAO, Laurenti R. Desigualdades nas condições de saúde e no uso de serviços de saúde entre as pessoas idosas do município de São Paulo: uma análise de gênero e renda. Saúde Coletiva 2008; 5:189-94.

11. Muntaner C, Borrell C, Benach J, Pasarín MI, Fernandez E. The associations of social class and social stratification with patterns of general and mental health in a Spanish population. Int J Epidemiol 2003; 32:950-8.

12. Arber S. Comparing inequalities in women's and men's health: Britain in the 1990's. Soc Sci Med 1997; 44:773-87.

13. Alves MCGP. ISA-Campinas 2008/09: plano de amostragem http://www.fcm.unicamp.br/cen tros/ccas/arquivos/plano_de_amostragem.pdf (accessed on 29/Mar/2012)

14. Barbor TE, La Fuente JR, Saunders J, Grant M. AUDIT - the alcohol use disorders identification test: guidelines for use in primary health care. Geneva: World Health Organization; 1992.

15. World Health Organization. Obesity: preventing and managing the global epidemic. Geneva: World Health Organization; 2000. (WHO Technical Report Series, 894)

16. Mari JJ, Williams P. A validity study of a psychiatric screening questionnaire (SRQ-20) in primary care in the city of Sao Paulo. Br J Psychiatry 1986; 148:23-6.

17. Barros MBA, Marín-León L, Oliveira HB, Dalgalarrondo P, Botega NJ. Perfil do consumo de bebidas alcoólicas: diferenças sociais e demográficas no Município de Campinas, Estado de São Paulo, Brasil, 2003. Epidemiol Serv Saúde 2008; 17:259-70.

18. Lima-Costa MF. A escolaridade afeta, igualmente, comportamentos prejudiciais à saúde de idosos e adultos mais jovens? Inquérito de Saúde da Região Metropolitana de Belo Horizonte, Minas Gerais, Brasil. Epidemiol Serv Saúde 2004; 13:201-8.

19. Malyutina S, Bobak M, Kurilovitch D, Nikitin Y, Marmot M. Trends in alcohol intake by education and marital status in urban population in Russia between the mid 1980s and the mid 1990s. Alcohol Alcohol 2004; 39:64-9.

20. Barros MBA, Botega NJ, Dalgalarrondo P, MarínLeón L, Oliveira HB. Prevalence of alcohol abuse and associated factors in a population-based study. Rev Saúde Pública 2007; 41:502-9.

21. Guimarães VV, Florindo AA, Stopa SR, César CLG, Barros MBA, Carandina L, et al. Consumo abusivo e dependência de álcool em população adulta no Estado de São Paulo, Brasil. Rev Bras Epidemiol 2010; 13:314-25.
22. Mendoza-Sassi RA, Beria JU. Prevalence of alcohol use disorders and associated factors: a populationbased study using AUDIT in southern Brazil. Addiction 2003; 98:799-804.

23. Barros MBA, Francisco PMSB, Lima MG, César CLG. Social inequalities in health among the elderly. Cad Saúde Pública 2011; 27 Suppl 2:S198-208.

24. Silva GA, Valente JG, Almeida LM, Moura EC, Malta DC. Tabagismo e escolaridade no Brasil, 2006. Rev Saúde Pública 2009; 43 Suppl 2:48-56.

25. Federico B, Costa G, Kunst AE. Educational inequalities in initiation, cessation, and prevalence of smoking among 3 Italian birth cohorts. Am J Public Health 2007; 97:838-45.

26. Malta DC, Moura EC, Silva SA, Oliveira PPV, Silva VLC. Prevalência do tabagismo em adultos residentes nas capitais dos estados e no Distrito Federal, Brasil, 2008. J Bras Pneumol 2010; 36:75-83.

27. Moura EC, Silva SA, Malta DC, Morais Neto OL. Fatores de risco e proteção para doenças crônicas: vigilância por meio de inquérito telefônico, VIGITEL, Brasil, 2007. Cad Saúde Pública 2011; 27 486-96.

28. Zanchetta LM, Barros MBA, César CLG, Carandina L, Goldbaum M, Alves MCGP. Inatividade física e fatores associados em adultos, São Paulo, Brasil. Rev Bras Epidemiol 2010; 13:387-99.

29. Jaime PC, Monteiro CA. Fruit and vegetable intake by Brazilian adults, 2003. Cad Saúde Pública 2005; 21 Suppl:S19-24.

30. Figueiredo ICR, Jaime PC, Monteiro CA. Factors associated with fruit and vegetable intake among adults of the city of São Paulo, Southeastern Brazil. Rev Saúde Pública 2008; 42:777-85.

31. Dachs JNW. Determinantes das desigualdades na auto-avaliação do estado de saúde no Brasil. Ciênc Saúde Coletiva 2002; 7:641-57.

32. Barros MBA, Zanchetta LM, Moura EC, Malta DC. Auto-avaliação da saúde e fatores associados, Brasil, 2006. Rev Saúde Pública 2009; 43 Suppl 2: 27-37.

33. Peres MA, Masiero AV, Longo GZ, Rocha GC, Matos IB, Najnie K, et al. Auto-avaliação da saúde em adultos no Sul do Brasil. Rev Saúde Pública 2010 44:901-11.

34. Barros MBA, Francisco PMSB, Zanchetta LM, César CLG. Tendência das desigualdades sociais na prevalência de doenças crônicas no Brasil, PNAD: 2003-2008. Ciênc Saúde Coletiva 2011; 16:3755-68.

35. Barreto SM, Figueiredo RC. Doença crônica, auto-avaliação de saúde e comportamento de risco: diferença de gênero. Rev Saúde Pública 2009; 43 Suppl 2:38-47.

36. Macintyre S, Der G, Norrie J. Are there socioeconomic differences in responses to a commonly used self report measure of chronic illness? Int J Epidemiol 2005; 34:1284-90.

37. Westert GP, Schellevis FG, de Bakker DH, Groenewegen PP, Bensing JM, van der Zee J. Monitoring health inequalities through general practice: the second Dutch National Survey of General Practice. Eur J Public Health 2005; 15:59-65. 
38. Lima-Costa MF, Barreto S, Giatti L. A situação socioeconômica afeta igualmente a saúde de idosos e adultos mais jovens no Brasil? Um estudo utilizando dados da Pesquisa Nacional por Amostras de Domicílios - PNAD/98. Ciênc Saúde Coletiva 2002; 7:813-24

39. Grebla RC, Rodriguez CJ, Borrell LN, Pickering TG. Prevalence and determinants of isolated systolic hypertension among young adults: the 1999-2004 U.S. National Health and Nutrition Examination Survey. J Hypertens 2010; 28:15-23.

40. Delpierre C, Lauwers-Cances V, Datta GD, Berkman L, Lang T. Impact of social position on the effect of cardiovascular risk factors on self-rated health. Am J Public Health 2009; 99:1278-84.

41. Rabiais S, Nogueira PJ, Falcão JM. A dor na população portuguesa: alguns aspectos epidemiológicos (2002). http://www.doentescomcancro.org/uhdc/ pdfs/EstudoDorPopulacaoPortuguesa.pdf (accessed on 18/Sep/2011).

42. Silva MC, Fassa AG, Valle NCJ. Dor lombar crônica em uma população adulta do Sul do Brasil: prevalência e fatores associados. Cad Saúde Pública 2004; 20:377-85.

43. Vogt M. Prevalência e severidade da dor, cervical e lombar, nos servidores técnico-administrativos da Universidade Federal de Santa Maria [Dissertação de Mestrado]. Florianópolis: Universidade Federal de Santa Catarina; 2000.

44. Castro SS, César CLG, Carandina L, Barros MBA, Alves MCGP, Goldbaum M. Deficiência visual, auditiva e física: prevalência e fatores associados em estudo de base populacional. Cad Saúde Pública 2008; 24:1773-82.

45. Rysculova A, Turczyn K, Makuc DM, Cotch MF, Klein RJ, Janiszewski R. Self-reported age-related eye diseases and visual impairment in the United States: results of the 2002 National Health Interview Survey. Am J Public Health 2008; 98:454-61.
46. Hung HC, Colditz G, Joshipura KJ. The association between tooth loss and the self-reported intake of selected CVD-related nutrients and foods among US women. Community Dent Oral Epidemiol 2005; 33:167-73.

47. Araújo CS, Lima RC, Peres MA, Barros AJD. Utilização de serviços odontológicos e fatores associados: um estudo de base populacional no Sul do Brasil. Cad Saúde Pública 2009; 25:1063-72.

48. Baldani MH, Brito WH, Lawder JAC, Mendes YBE Silva FFM, Antunes JLF. Determinantes individuais da utilização de serviços odontológicos por adul tos e idosos de baixa renda. Rev Bras Epidemiol 2010; 13:150-62.

49. Instituto Brasileiro de Geografia e Estatística. Um panorama da saúde no Brasil: acesso e utilização dos serviços de saúde, condições de saúde e fatores de risco e proteção à saúde, 2008. Pesquisa Nacional por Amostra de Domicílios - PNAD 2008. Rio de Janeiro: Instituto Brasileiro de Geografia e Estatística; 2010.

50. Gilbert HG. Access to and patterns of use of oral health care among elderly veterans. Med Care 1995; 33:78-89.

51. Moreira RS, Nico LS, Tomita NE, Ruiz T. A saúde bucal do idoso brasileiro: revisão sistemática sobre o quadro epidemiológico e acesso aos serviços de saúde bucal. Cad Saúde Pública 2005; 21:1665-75.

52. Departamento de Ações Programáticas e Estratégicas, Secretaria de Atenção à Saúde, Ministério da Saúde. Plano de Ação Nacional 2009-2011 da Política Nacional de Atenção Integral à Saúde do Homem. Brasília: Ministério da Saúde; 2009.

Submitted on 24/Nov/2011

Final version resubmitted on 09/Apr/2012

Approved on 17/Apr/2012 